\title{
Pineapple stem-derived bromelain based priming improves pepper seed protein reserve mobilization and germination
}

Lianny Pérez

Bioplant Centre

Yanier Acosta

Bioplant Centre

Lelurlys Nápoles

Bioplant Centre

Carol Carvajal

Bioplant Centre

Claudia Linares

Bioplant Centre

\section{Sershen Sershen}

University of the Western Cape

Jose Carlos Lorenzo Feijoo ( $\boldsymbol{}_{\text {jclorenzo@bioplantas.cu ) }}$

University of Ciego de Avila https://orcid.org/0000-0003-3610-1789

Aurora Pérez

Bioplant Centre

\section{Short Report}

Keywords: Ananas comosus (L.) Merr, Capsicum annuum L., plant natural products, proteolytic activity

Posted Date: April 8th, 2021

DOl: https://doi.org/10.21203/rs.3.rs-355995/v1

License: (c) (1) This work is licensed under a Creative Commons Attribution 4.0 International License. Read Full License 


\section{Abstract}

Pepper fruit has a great agronomic, nutritional and commercial value given that it is rich in antioxidant compounds such as carotenes, and vitamins $\mathrm{C}$ and $\mathrm{E}$. However, pepper seeds are slow to germinate and emergence is often non-uniform and incomplete. Seed priming and invigoration treatments have been explored for a number of pepper varieties but success has been variable and generally limited. The present report describes the effects of pineapple stem - derived protease (stem bromelain) based priming on pepper seed germination in relation to reserve mobilization (specifically, proteins and aminoacids). Germination capacity in bromelain treated seeds was significantly higher on days 7, 14 and 21 than in unsoaked (control) and deionized water-soaked seeds but comparable across the treatments and the control on day 28. Germination rate was significantly highest in bromelain treated seeds. Light microscopy revealed an abundance of protein bodies in the endosperm of the seeds investigated at before imbibition and when observed over a period of $96 \mathrm{~h}$, these bodies were progressively degraded, with the rate of this degradation being fastest in bromelain treated seeds. Quantitative measurements of protein levels (and free amino content) confirmed this observation. The results motivate the use of bromelain extracts for priming pepper seeds based on their proteolytic activity, since germination is dependent on the availability of crude protein and essential amino acids.

\section{Introduction}

Pepper (Capsicum annuum L.) fruit has a great agronomic, nutritional and commercial importance based on its high levels of antioxidant compounds such as carotenes, and vitamins $\mathrm{C}$ and $\mathrm{E}$ (Chávez-Mendoza et al. 2015). According to the Food and Agriculture Organization (FAO), world's production of pepper reached $4164594 \mathrm{t}$ in 2018 (FAOSTAT 2018). However, seedling establishment in this cash crop is often not maximized owing to the low speed and uniformity in the germination exhibited by pepper seeds (Demir et al. 2018).

As in other vegetable species (Delian et al. 2017; Anwar et al. 2020), efforts have been made to ameliorate these undesirable seed traits in pepper seeds (Bradford et al. 1990; Andreoli and Khan 1999). For example, Dutta et al. (2015) reported that $\mathrm{K}_{2} \mathrm{SO}_{4}(1 \%)$ priming exerted a positive influence via increasing pepper seed germination percentage by $31.29 \%$ compared to non primed seeds. Siri et al. (2013) reported that seeds primed in a polyethylene glycol (PEG 6000) solution with the osmotic potential of -1.5 MPa for 6 days improved germination compared to control seeds. The disadvantages of using these chemical substances as priming agents is that the cost of osmotics such as PEG is high, and they also present obstacles to their commercialization due to their relative complexity. In addition, they must be removed from the seeds before they dry out. Studies on the priming of peppers seeds with plant extracts are rare (Barchenger and Bosland 2016), and to the best of our knowledge, bromelain extracts from pineapple stems has never been used to prime pepper seeds.

Proteases play an important role in mobilizing protein reserves in seeds (Zhao et al. 2018). Cysteine proteases are the most abundant group of proteases responsible for the degradation and mobilization of 
reserve proteins to promote seed germination (Grudkowska and Zagdańska 2004). Bromelain is a cysteine protease (Heinicke and Gortner 1957) with several applications in fields such as medicine and biotechnology (Mohri and Matsushita 1984; Carvajal et al. 2010; Zhao et al. 2013; Kwatra 2019). In 1997, the Bioplant Centre patented a simple and efficient new technology to obtain bromelain from pineapple stems (harvest remains) (Hernández et al. 1997). Reference to the literature indicated only one study, published in 1994, where the effect of exogenous bromelain application on germination was assessed. This study, which was conducted on the seeds of Rosa multiflora Thunb (Kuska 1994), used reagent grade bromelain from stem of pineapple and increased seed germination percentage three times compared to unprimed seeds. However, studies on bromelains potential mechanism(s) of action in terms of its effects on the biochemical processes that influence germination were not conducted. This motivated the present report which describes the use of pineapple stem - derived bromelain for pepper seed priming. Seed germination capacity and rate were related to levels of proteins and aminoacids to identify bromelains potential mechanism of action in this species. Light microscopy was also used to assess levels of protein degradation during imbibition.

\section{Materials And Methods}

\section{Plant materials}

Sweet pepper seeds cv. Lamuyo were obtained from the Ceballos Agro-Industrial Company, Ciego de Ávila, Cuba. Bromelain crude extract was obtained from pineapple cv. MD-2 stems from harvest residues. Extraction was performed using the procedure described by Hernández et al. (1997) with $2 \mathrm{mmol} / \mathrm{L}$ sodium sulphite to stabilize the active centers of the enzyme.

\section{Seed treatments and assessment}

Seeds were soaked in bromelain crude extract with a proteolytic activity of $6.25 \mathrm{tU}$ or deionized water for $3 \mathrm{~h}$ at $35^{\circ} \mathrm{C}$ in $100 \mathrm{~mL}$-Erlenmeyers without shaking in the dark. The optimal duration of pepper seed priming was previously determined in our laboratory (unpublished data). Unsoaked seeds served as a control. One total $U$ is defined as the amount of enzyme, in the total volume of extract used, that liberates $1 \mu \mathrm{mol}$ of soluble TCA. One hundred pepper seeds (4 reps of 25 seeds / Erlenmeyers) were used per treatment and control. Later seeds were dried at $25^{\circ} \mathrm{C}$ for $48 \mathrm{~h}$ until reaching their initial mass $(8.5 \mathrm{mg} \pm$ $0.61 \mathrm{mg}$ per seed). For germination, all treatments were placed in Petri dishes on filter paper moistened with $10 \mathrm{~mL}$ of deionized water. A germination chamber (RTOP-D Series, China) was used at $30 \pm 2^{\circ} \mathrm{C}$ for 28 days. During the first five days they were kept in the dark and later in a photoperiod of $16 \mathrm{~h}$ of light / 8 $\mathrm{h}$ of darkness. Germination was recorded daily and this data were used to calculate the germination rate according to Ranal and Santana (2006).

\section{Histochemical evaluation of protein bodies in pepper seeds}

A separate batch of 125 pepper seeds ( 5 reps of 25 seeds / Erlenmeyer) were used per treatment and control for histochemical evaluation as described above. Twenty seeds per treatment and control were 
randomly sampled (4 seeds / rep) at 0, 24, 48, 72 and $96 \mathrm{~h}$ for the histochemical analysis (Johansen 1940). Samples were fixed in FAA, dehydrated in an ethanol series, and embedded in paraffin. Cross sections ( $5 \mu \mathrm{m}$ thick) were cut with a hand rotary microtome KD-202A and collected on microscopic slides covered with a gelatin solution. Sections were stained with solutions of mercury (1\%) and blue bromophenol (0.05\%) according to Pearse (1985). Observations were carried out using a Carl Zeiss Microlmaging (GmbH 37081) microscope at 20x, and images captured with a Cannon (EOS 600D) digital camera.

\section{Levels of soluble proteins and free aminoacids in pepper seeds}

Another separate batch of 125 pepper seeds ( 5 reps of 25 seeds / Erlenmeyer) were used per treatment and control for measuring levels of soluble proteins and free aminoacids. Twenty seeds per treatment were randomly sampled ( 4 seeds / rep) at $0,24,48,72,96$ and $120 \mathrm{~h}$ for protein and free aminoacids evaluation. Protein extraction was carried out with Tris-HCl $0.1 \mathrm{~mol} / \mathrm{L}$ buffer, $\mathrm{pH}=8.5-8.8,5 \mathrm{mmol} / \mathrm{L}$ EDTA and $20 \mathrm{mmol} / \mathrm{L} \beta$-mercaptoethanol (Isaacson et al. 2006). The total protein content was determined according to Bradford (1976). The amino acid extraction of each sample was carried out twice with ethanol $(80 \%, \mathrm{v}: \mathrm{v})$ and both supernatants were combined. Quantification of the total amino acid content was carried out through ninhydrin reaction according to Moore and Stein (1948). Biochemical analyzes of each sample were replicated three times.

\section{Data analysis}

The quantitative data collected were analyzed using SPSS (Version 8.0 for Windows, SPSS Inc., New York, NY). Data were subjected to t-, ANOVA and Tukey tests $(p=0.05)$ after normality was established (Shapiro-Wilk test).

\section{Results And Discussion}

The mobilization of reserves (proteins, carbohydrates and lipids) is crucial for germination efficiency and establishment of seedlings (Thompson 2018). Abud et al. (2017) pointed out that proteins constitute one of the main reserve components in Capsicum annuum L. seeds. Galão et al. (2007) observed in the seeds of Prosopis juliflora after $48 \mathrm{~h}$ under germination conditions, that the globular protein bodies were hydrolyzed and the protein material became more soluble. The hydrolysis of reserve proteins to their constituent amino acids is carried out by proteases, both during germination and in post-germination processes (Zhao et al. 2018).

In the present study, bromophenol blue staining developed a strong blue coloration of the cytoplasmic granules suggesting the presence of protein bodies in vacuoles of the endosperm of seeds in all treatments (Fig. 1). Numerous protein bodies were observed in pepper seed endosperm at the beginning of the imbibition period (Fig. 1A). Their number was reduced progressively during the first $96 \mathrm{~h}$ of germination in all treatments, although protein degradation appeared to be markedly faster (more 
extensive) in bromelain primed seeds (Fig. 1B). More specifically, during the first $96 \mathrm{~h}$ of observation, higher protein disintegration (less intense coloration) was observed in bromelain-treated seeds compared with untreated (control) and hydro-primed seeds (Fig. 1B). After 48 h, a greater spacing and dispersion of the protein bodies of the seeds conditioned with crude bromelain extract was observed (Fig. 1). Quantitative analysis of protein levels confirmed this observation (Fig. 2A). The bromelain treatment also increased levels of free aminoacids (Fig. 2B). Percentage of germination (Fig. 3) and germination rate (Fig. 4) were initially higher in bromelain-treated seeds. However, final germination percentage was comparable across the treatments and the control.

Several authors have reported on the predominance of cysteine-proteases during the degradation processes of reserve proteins (Szewińska et al. 2016; Liu et al. 2018). Tozzi and Takaki (Tozzi and Takaki 2011) observed in seeds of Passiflora edulis the degradation of the protein bodies and the loss of these began generating spaces product of the mobilization of reserves from the sixth day of being placed in germination conditions. The biochemical analyses carried out here indicate that the content of protein reserves decreased fastest in the bromelain-treated seeds, most likely as a result of hydrolysis by the action of the proteolytic activity of bromelain (cysteine-protease) (Kwatra 2019; Mendes et al. 2019) and other proteases present in the seed.

The content of free amino acids was in agreement with these observations. The relationship observed between the content of soluble proteins and free amino acids has been described in seeds of different plants during the mobilization of reserves. In a study conducted by Satyanarayana et al. (2011) on Sterculia urens Roxb. observed a decrease in the content of soluble proteins in the cotyledons while an increase in the content of free amino acids occurred over time during the $9 \mathrm{~d}$-germination period. Aragão et al. (2015) also observed a significant decrease in ethanol-soluble proteins and an increase in the total content of free amino acids during germination (5-7 days) of Cedrela fissilis Vellozo seeds, which suggests that amino acids could be provided by the mobilization of proteins stored in mature seeds.

The results of the present study indicate that the priming of the seeds with crude bromelain extract has a beneficial effect on the pepper seeds, increasing their initial germination percentage and rate. As alluded to above the hydrolysis of storage proteins promoting the mobilization of protein reserves and therefore the generation of amino acids. The amino acids obtained can then be used in the biosynthesis of enzymes, hormones, proteins, pyrimidines and purine bases, which contributes to the germinative development of the embryo (Aragão et al. 2015). In addition, the crude bromelain extract contains other compounds such as minerals, sugars, vitamins and amino acids that may have accelerated the development of the embryo and contributed to increasing the speed of germination, which coincides with that indicated by Mavi and Atak (2016). The results collectively motivate for the use of bromelain extracts for priming pepper seeds, since the hastening of germination through increased reserve mobilization during the early stages of germinative development can promote seedling establishment.

\section{Declarations}


Author contribution: LP, YA, LN, CC, CL, S, JCL and AP designed the research; LP, YA, LN, CC and CL conducted the experiments; LP, YA, S, JCL and AP analyzed the data; LP, YA, S, JC and AP wrote the paper; $S, J C L$ and AP had primary responsibility for the final content. All authors have read and approved the final manuscript.

Acknowledgements This research was supported by the Bioplant Centre and the Faculty of Agriculture of the University of Ciego de Ávila Máximo Gómez Báez (Cuba); the University of the Western Cape (South Africa); and the Institute of Natural Resources (South Africa). Authors are grateful to Dr. Evelio Baéz and Mr. Gustavo Lorente for their important scientific suggestions; and to Mrs. Yemeys Quirós, Mrs. Maribel Rivas and Mr. Danilo Pina for their skilled technical assistance. Authors are also grateful to the Ceballos Agro-Industrial Company (Ciego de Ávila, Cuba) for donating pepper seeds.

Conflict of interest Authors do not have any conflict of interests.

Human and animal rights This research did not involve experiments with human or animal participants.

Informed consent Informed consent was obtained from all individual participants included in the study. Additional informed consent was obtained from all individual participants for whom identifying information is included in this article.

\section{References}

Abud HF, Araújo EF, Araujo RF, Picoli EAdT, Gallão MI (2017) Histochemical changes during the ontogeny of malagueta and biquinho pepper seeds. Acta Scient Agron 39:535-543

Andreoli C, Khan AA (1999) Matriconditioning integrated with gibberellic acid to hasten seed germination and improve stand establishment of pepper and tomato. Pesq Agrop Bras 34:1953-1958

Anwar A, Xianchang Y, Yansu L (2020) Seed priming as a promising technique to improve growth, chlorophyll, photosynthesis and nutrient contents in cucumber seedlings. Not Bot Horti Agroboti Cluj-Nap 48:116-127

Aragão VPM, Navarro BV, Passamani LZ, Macedo AF, Floh EIS, Silveira V, Santa-Catarina C (2015) Free amino acids, polyamines, soluble sugars and proteins during seed germination and early seedling growth of Cedrela fissilis Vellozo (Meliaceae), an endangered hardwood species from the Atlantic Forest in Brazil. Theor Exp Plant Physiol 27:157-169

Barchenger DW, Bosland PW (2016) Exogenous applications of capsaicin inhibits seed germination of Capsicum annuum. Sci Hort 203:29-31

Bradford KJ, Steiner JJ, Trawatha SE (1990) Seed priming influence on germination and emergence of pepper seed lots. Crop Science 30:718-721 
Bradford MM (1976) A rapid and sensitive method for the quantification of microgram quantities of protein utilising the principle of protein-dye binding. Analyt Biochem doi: 101006/abio19769999 72:248254

Carvajal C, Márquez M, Pérez A, Chávez M, Hernández M (2010) Caracterización cinética de un preparado semipurificado de bromelina para uso antitumoral. Rev Cub Plantas Medic 15:27-41

Chávez-Mendoza C, Sanchez E, Muñoz-Marquez E, Sida-Arreola J, Flores-Cordova M (2015) Bioactive compounds and antioxidant activity in different grafted varieties of bell pepper. Antioxidants 4:427-446

Delian E, Bădulescu L, Dobrescu A, Chira L, Lagunovschi-Luchian V (2017) A brief overview of seed priming benefits in tomato. Rom Biotech Lett 22:12505-12513

Demir I, Ozden E, Yıldırım K, Sahin O, Van Staden J (2018) Priming with smoke-derived karrikinolide enhances germination and transplant quality of immature and mature pepper seed lots. South Afr J Bot $115: 264-268$

Dutta SK, Singh AR, Boopathi T, Singh SB, Singh MC (2015) Effects of priming on germination and seedling vigour of bird's eye chilli (Capsicum frutescens $\mathrm{L}$.) seeds collected from eastern himalayan region of India. The Bioscan 10:279-284

FAOSTAT (2018) Production quantities of Chillies and peppers, dry by country. Available http://www.fao.org/faostat/en/\#data/QC/visualize. Accessed November 11, 20182020

Gallão M, Vieira Í, Mendes F, de Souza A, de Brito E (2007) Reserve mobilisation in mesquite (Prosopis juliflora) seed (Leguminosae). J Sci Food Agri 87:2012-2018

Grudkowska M, Zagdańska B (2004) Multifunctional role of plant cysteine proteinases. Acta Biochim Pol 51:609-624

Heinicke RM, Gortner WA (1957) Stem bromelain-a new protease preparation from pineapple plants. Econ Bot 11:225-234

Hernández M, Chávez M, Márquez M, Rodríguez G, Santos R, González J, Carvajal C (1997) Proceso de obtención de bromelina a partir de tallos de piña. Patente Cubana C12N 9:50

Isaacson T, Damasceno CM, Saravanan RS, He Y, Catalá C, Saladié M, Rose JK (2006) Sample extraction techniques for enhanced proteomic analysis of plant tissues. Nat Prot 1:769

Johansen DA (1940) Plant microtechnique McGraw-Hill, New York, pp 528.

Kuska H (1994) Improvement of rose germination with household enzymes Departament of Chemistry, University of Akron, Ohio, 
Kwatra B (2019) A review on potential properties and therapeutic applications of bromelain. WORLD J Pharm Pharm Sci 8:488-500

Liu H, Hu M, Wang Q, Cheng L, Zhang Z (2018) Role of papain-like cysteine proteases in plant development. Front Plant Sci 9:1717

Mavi K, Atak M (2016) Effect of organic priming on seedling emergence of watermelon under low temperature stress. Proc 7th Int Scientif Agric Symp "Agrosym":1727-1732

Mendes MLT, Marques E, do Nascimento J, Machado-Reinheimer D (2019) Efficacy of proteolytic enzyme bromelain on health outcomes after third molar surgery. Systematic review and meta-analysis of randomized clinical trials. Med Oral Pat Oral Cir Bucal 24:e61

Mohri M, Matsushita S (1984) Improvement of water absorption of soybean protein by treatment with bromelain. J Agric Food Chem 32:486-490

Moore S, Stein WH (1948) Photometric nin-hydrin method for use in the ehromatography of amino acids. J Biol Chem 176:367-388

Pearse AGE (1985) Histochemical: Theoretical and Applied, Churchill, London,

Satyanarayana B, Devi PS, Arundathi A (2011) Biochemical changes during seed germination of Sterculia urens Roxb. Not Sci Biol 3:105-108

Siri B, Vichitphan K, Kaewnaree P, Vichitphan S, Klanrit P (2013) Improvement of quality, membrane integrity and antioxidant systems in sweet pepper (Capsicum annuum L.) seeds affected by osmopriming. Aust J Crop Sci 7:2068

Szewińska J, Simińska J, Bielawski W (2016) The roles of cysteine proteases and phytocystatins in development and germination of cereal seeds. J Plant Physiol 207:10-21

Thompson RD (2018) Storage Protein Synthesis. eLS:1-9

Tozzi H, Takaki M (2011) Histochemical analysis of seed reserve mobilization in Passiflora edulis Sims fo. flavicarpa O. Deg.(yellow passion fruit) during germination. Braz J Biol 71:701-708

Zhao LC, Chen JL, Wang Y, Liu X (2013) Study on the structure-activity relationship of stem bromelain in different inhibitors and activators. J Sci Technol Food Ind 15

Zhao M, Zhang H, Yan H, Qiu L, Baskin CC (2018) Mobilization and role of starch, protein, and fat reserves during seed germination of six wild grassland species. Frontiers in plant science 9:234

\section{Figures}



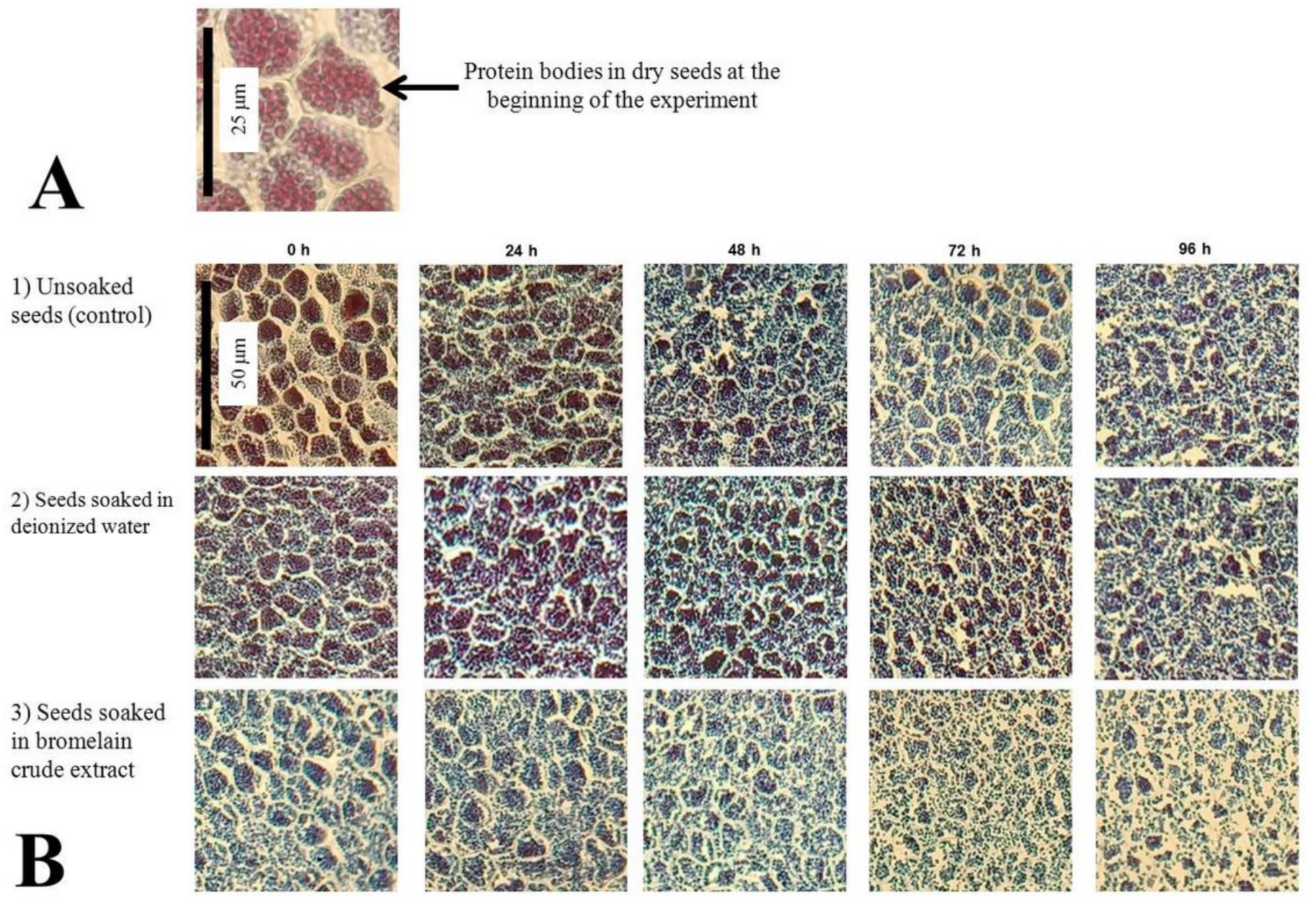

Fig. 1: Protein levels in Capsicum annuum L. endosperm during germination in Petri dishes after priming. A Protein bodies observed in the endosperm at the beginning of the experiment. B Progressive degradation of protein bodies during germination $(0-96 \mathrm{~h})$ which was faster in seeds treated with bromelain.

\section{Figure 1}

In the present study, bromophenol blue staining developed a strong blue coloration of the cytoplasmic granules suggesting the presence of protein bodies in vacuoles of the endosperm of seeds in all treatments (Fig. 1) 

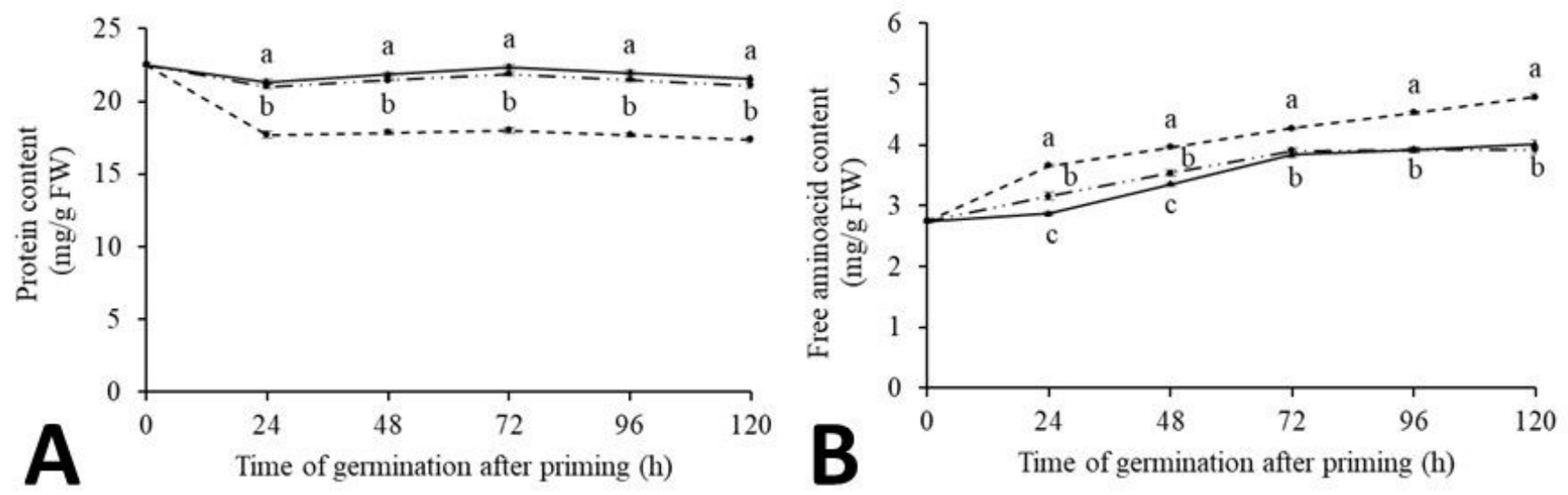

Treatment of seeds before germination in Petri dishes:

- Unsoaked seeds (control)

-.... Seeds soaked in deionized water

-...-.- Seeds soaked in bromelain crude extract

Fig. 2: A Soluble protein levels in Capsicum anmuum L. seeds during germination in Petri dishes after priming. B Levels of free aminoacids. Results with the same letter are not statistically different when compared within time intervals (t-test, $\mathrm{p}>0,05$ ). Vertical bars represent $\pm \mathrm{SE}$.

\section{Figure 2}

Quantitative analysis of protein levels confirmed this observation (Fig. 2A). The bromelain treatment also increased levels of free aminoacids (Fig. 2B). 


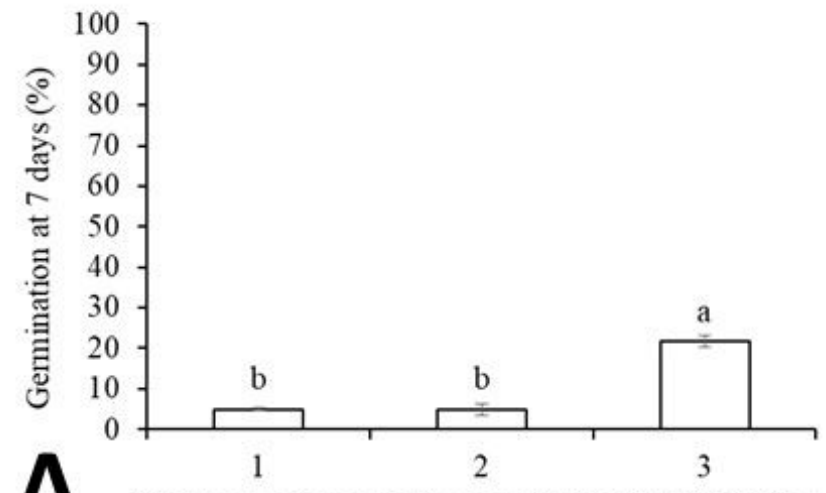

$\Delta$ Treatment of seeds before germination in Petri dishes

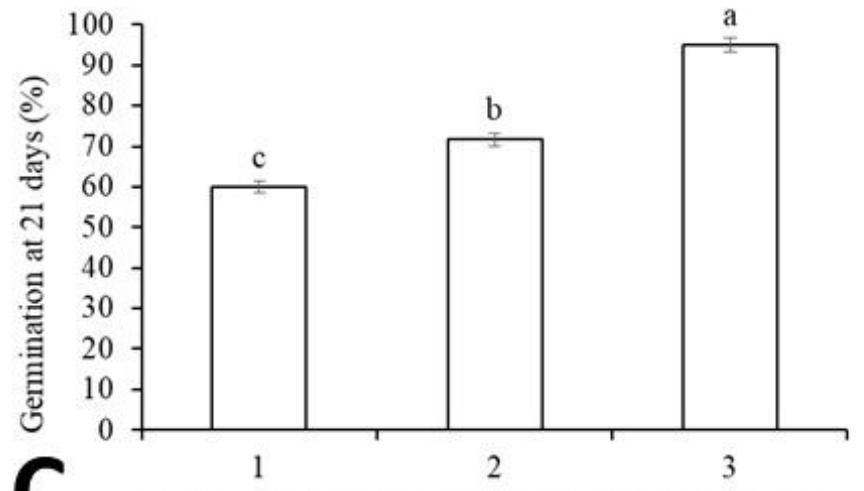

Treatment of seeds before germination in Petri dishes
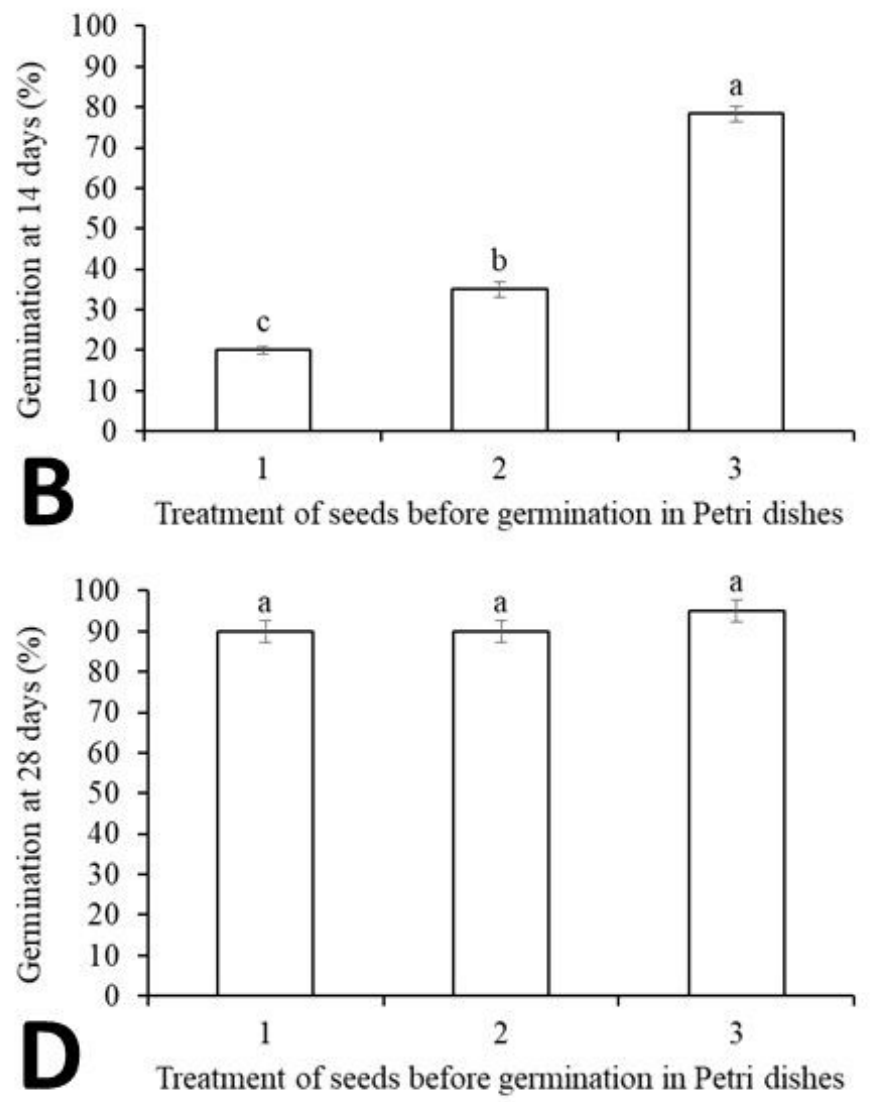

Fig. 3: Germination percentages at 7 (A), 14 (B), 21 (C) and 28 days (D). Legend: 1) Unsoaked seeds (control); 2) Seeds soaked in deionized water; 3 ) Seeds soaked in bromelain crude extract. Results with the same letter are not statistically different (One-Way ANOVA, Tukey, $\mathrm{p}>0,05$ ). Vertical bars represent $\pm \mathrm{SE}$.

\section{Figure 3}

Percentage of germination (Fig. 3) and germination rate (Fig. 4) were initially higher in bromelain-treated seeds. However, final germination percentage was comparable across the treatments and the control. 


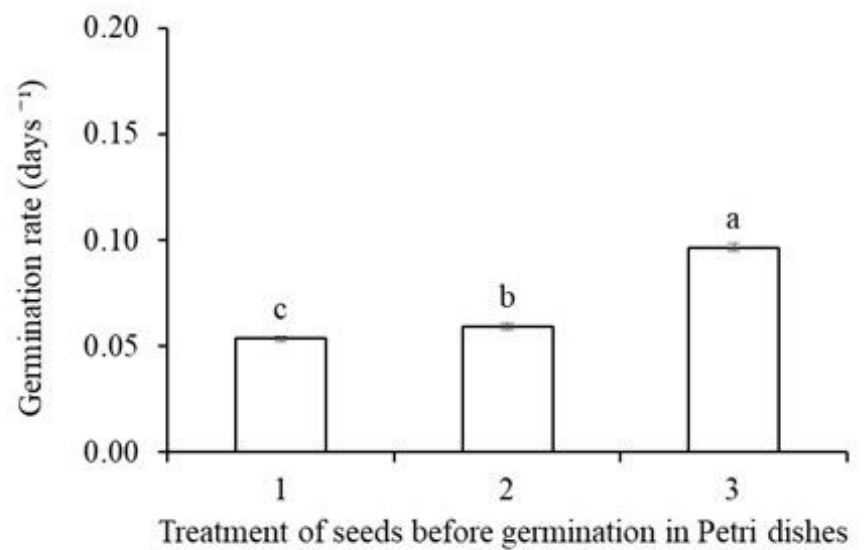

Fig. 4: Germination rate calculated over the 28 days of germination period. Legend: 1) Unsoaked seeds (control); 2) Seeds soaked in deionized water; 3 ) Seeds soaked in bromelain crude extract. Results with the same letter are not statistically different (One-Way ANOVA, Tukey, $p>0,05$ ). Vertical bars represent $\pm S E$.

\section{Figure 4}

Percentage of germination (Fig. 3) and germination rate (Fig. 4) were initially higher in bromelain-treated seeds. However, final germination percentage was comparable across the treatments and the control. 